\title{
AZ ÓKORI MEZOPOTÁMIA KATONÁI - 2. RÉSZ
}

\section{Szerzők:}

Fejes Zsolt (PhD)

Magyar Honvédség Egészségügyi Központ

Helyes Marcell

Karl-Franzens Universitat (Ausztria)

Mihók Sándor (Dr. Jur.)

nyugalmazott jogtanácsos

Első szerző e-mail címe:

zsoltfejesdr@yahoo.com

\section{Lektorok:}

Kóródi Gyula (Prof. Dr.)

Nemzeti Közszolgálati Egyetem

Rikk János (PhD)

Kodolányi János Egyetem

...és további két anonim lektor

\begin{abstract}
Absztrakt
A cikksorozat második részében folytatjuk az ókori Közel-Kelet birodalmai közül Mezopotámia hadseregeinek áttekintését. A cikksorozat első részéhez hasonlóan a Kr. e III. évezredtől a Kr. e 7. századig terjedő időszakot vizsgáljuk. Jelen tanulmányban részletesen ismertetjük újasszír kor legjelentősebb hadseregeit és katonai szervezetét, a birodalom hadseregeinek korspecifikus jellemzőit, összegezzük az időszakra jellemző, a kor katonáinak juttatásaira vonatkozóan irodalmi adatokat. Kitérünk a korszak sorozott és önkéntességen alapuló hadseregeiben szolgáló - köz, hivatásos és zsoldos - katonák „pénzbeli” (Lóránt, 2018), és természetbeni juttatásainak ismertetésére, valamint a harcban elesett katonák özvegyeinek és árváinak kezdetleges ellátási rendszerére.
\end{abstract}

Kulcsszavak: Asszíria, juttatás, ellátási rendszer

Diszciplinák: történelem, hadtudomány

\section{Abstract \\ SOLDIERS OF THE ANCIENT MESOPOTAMIA - PART 2}

In the second half of our series of articles, we continue the overview of the armies of the ancient empires of the Middle East. Similarly to the first half of our study, we analyze the 3rd millennium BC until the 7th century BC. In this article we describe in detail the most significant armies and military organizations of the Neo-Assyrian Empire, the characteristics of the empire's armies which are specific to the era, and we also summarize the data in 
literature about the allowances of the soldiers of this age. We also outline the monetary allowances and contributions in kind of the enlisted and voluntary -private, regular and mercenary- soldiers of the age as well as the service system for widows and orphans of soldiers, who were injured or died in battle.

Keywords: Assyria, allowance, service system

Disciplines: history, military science

Fejes Zsolt, Helyes Marcell és Mihók Sándor (2020): Az ókori Mezopotámia katonái - 2. rész. Lélektan és hadviselés - interdiszciplináris folyóirat, II. évf. 2020/1. szám. 45-54. doi: 10.35404/LH.2020.1.45

\section{Az Újasszír Birodalom hadserege és katonái}

Asszíria a Tigris és az Eufrátesz felső folyása mentén, Mezopotámiától északnyugati irányba elhelyezkedő, mezőgazdasági mûvelésre többnyire alkalmatlan, de vasércben gazdag területet jelentette. Egységes állam itt a Kr. e. III. és a II. évezred fordulóján jött létre, mely az alapító törzs, illetve a törzsi istenség nevét vette fel. Az asszír birodalom hódító politikájáról és kegyetlen, barbár hadviseléséről volt ismert. Fejlett haditechnikájuk, legfőképpen pedig vasfegyvereik, a vasmûvesség és a kovácsmesterség kiemelten fontos szerepet játszott a birodalom felemelkedésben.

A vasművesség birtokában lévő birodalmak, így az asszírok is monopóliumra törekedtek, igyekeztek más országokat, népeket bármilyen eszközzel - korlátozni a vas bármilyen célú felhasználásában, használatában (Pais,1993). Az asszírok a leigázott népeket rendszerint lemészárolták, vagy százezres nagyságrendben erőszakos módon áttelepítették.
Kétségtelen, hogy a fennmaradt ábrázolások és leírások szerint a brutális kínzási és kivégzési eljárások (karóba húzás, megnyúzás és kibelezés, elevenen elrothasztás, hamuba fullasztás) mai szemmel szadizmusról tanúskodnak, ám a cél az uralkodói szándék szerint egyértelműen hatalompolitikai és rendfenntartó volt: félelmet kelteni a potenciális külső és belső ellenségben, a behódolási készséget fokozni és az alattvalókat fegyelmezni. Az ókori Közel-Kelet közgondolkodásában az uralkodó hatalmának nagyságát megsemmisítő, ölési képességeivel mérték: ez is ésszerű magyarázata a védtelen hadifoglyok, meghódított városlakók tömeges kivégzésének (Dömötörfi, 2010)

Az ilyen módon hazájuktól és kultúrájuktól elszakított fiatal férfiak katonai utánpótlást jelentettek az asszír haderő számára, míg az áttelepítettek többségével kietlen, hadi felvonulási területeket mûveltettek meg. A leigázott népek deportálásának módszere a lázon- 
gások megelőzése, illetve elfojtása szempontjából is hasznosnak bizonyult.

A militáns asszír állam társadalma a babiloninál jóval kevésbé volt differenciált. Az Óbabiloni Birodalomhoz képest nagy létszámú papság sem jött létre. A földtulajdonjog hódítás jogán a királyt illette, bár ténylegesen a föld nagy része a fótisztviselők és a katonai vezetôk, az ún. hatalmasok (,rube”) kezében volt. A földek megmúvelését a bérmunkások és a félszabad foglyok végezték. Az újasszír korban (Kr. e. 911 - 612 között) az áttelepített népekből jött létre a telkes parasztok rétege, akiket a földdel együtt adtak a földbirtokosoknak úgy, hogy a tulajdonjog ekkor is a királyé maradt (Kajtár és Hergerné, 2014).

A III. Tukulti-apil-Esarra (a bibliai Tiglatpileszer, Kr. e. 744-727) által újjászervezett asszír haderô félelmetes erőt képviselt, melynek nem volt párja a korabeli világban. Utódai uralkodásának idején érte el az Újasszír birodalom a legnagyobb kiterjedését. Hatalmas területeket foglaltak el Babilóniában, Délnyugat-Iránban, Kelet-Anatóliában, Szíriában és Palesztinában, de még ennél is nagyobb területeket kényszerítettek adófizetésre (Kalla, 2003). Ezért korántsem meglepó, hogy az asszír katonaállam harcias uralkodói írásban és képben kellő módon gondoskodtak róla, hogy háborúikról és katonaságukról a legapróbb részletekre menően felvilágosítsák az utókort.

A háborúból és ennek következtében állandó háborúban élő országnak, amelyben külön feljegyzésre méltó eseményszámba ment, ha az uralkodó valamely évben nem járta hadai élén a külföldet, kitűnően szervezett, felszerelt és fegyelmezett és állandóan fegyverben álló hadseregre volt szüksége (Dávid, 1928).

Az asszír hadsereg területi alapon szerveződött és újoncozási, fenntartási és irányítási szempontból két részből állt: a királyi (,,kișir saarrüti”) és a tartományi feltöltésủ királyi alakulatokból (șäb šarri, a „király emberei”). A királyi alakulatok önmagukban is több csoportra voltak oszthatók: egyrészt öt városi (,Ašsuräia”, Arraphāià", „Arzuhinäia", „Arbailäia” és „Armäia”) alakulatra, másrészt három féle testőralakulatra (,Qurubtu lovas-


lyi alakulatok az asszír magterületen, a „király emberei" pedig távolabbi tartományokban állomásoztak, állományukat a helybeli lakosságból, a deportáltakból vagy a hadifoglyokból sorozták (Dezső, 2015).

A Qurubtu lovasság az uralkodó személyi védelmét ellátó közel 1000 fős testőralakulat volt. Elnevezésük is találó volt: „azok, akik baráti vagy ellenséges helyen nem tágítanak a lábam mellől.” A többi testöralakulat alapvetően vidéken és a határszéleken állomásozott. Érdekesség, hogy ezeknél az alakulatoknál nem volt feltétel, hogy a katona született asszír legyen. A feltétel egyértelmű volt: a jelöltnek rendíthetetlen hűséggel és bátorsággal kellett szolgálnia királyát (Saggs, 1965).

A Qurubtu lovasság jelentőségét igazolja, hogy „II. Sarrukín Kr. e. 714-ben, a Wauš-hegy melletti csatában úgy győzte le Rusa urartui király alakzatban felállt seregét, hogy harci kocsiján állva maga vezette 1000 testőrlovasának mindent elsöprő rohamát. Ez a lovasroham úgy csapódott 
be az urartui hadrend közepébe, mint egy nyíl és szörnyű mészárlást vitt véghez a soraiban” (Dezső,2011, 134. o.)

Figyelemre méltó újítás, hogy a vasból készült küllős kerekű, lóval vontatott harci szekerek (1. ábra) - melynek parancsnokai a katonai arisztokrácia tagjai voltak - már Kr. e. 1100 körül önálló, mai kifejezéssel élve „elit” fegyvernemet alkottak az asszír seregben.

A Kr. e. 9. században pedig megjelent az ijász-lovasság is önálló fegyvernemként. A harciszekér osztagok és lovasok mellett a gyalogságon belül is különváltak a gyalogos ijászok, a lándzsások, a parittyások, végül az ugyancsak több csoportra tagozódó „,műszaki csapatok".

\section{1. ábra: Asszír harciszekeér. Forrás: Net1.}

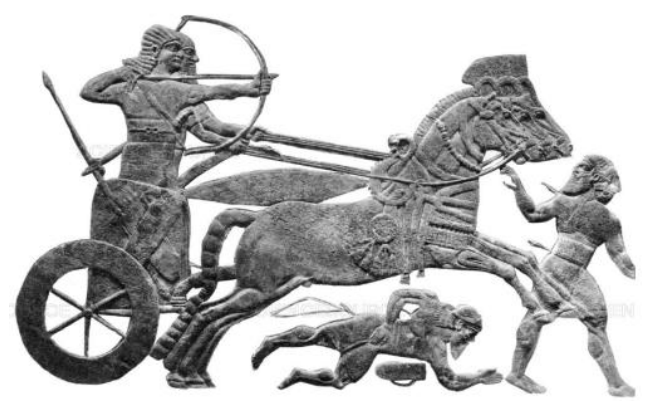

A műszaki csapatoknak köszönhetően az asszír hadsereg rendkívül magas színvonalú ostromtechnikát alkalmazott. Ostromtechnikájuk alapelveiben (körülzárás és roham kombinációja), valamint egyes technikai eljárásaiban (faltörőkos, ostromtorony, ostromlétra) példaképévé vált a perzsa, majd később a hellenisztikus, a római és a középkori ostrom művészetnek is.

A százezer főt meghaladó, addig példátlan létszámú hadsereg, amelyhez még írnokok, tolmácsok, hírszerzők és jósok (!) is tartoztak, minden korábbi birodalomnál jóval magasabb szintre emelte a fegyelmezést, a kiképzést és a fegyverzetet (Hahn, 1963; Klíma, 1983).

Összességében megállapítható, hogy az asszír hadsereg volt az ókor egyik legbonyolultabb, legösszetettebb hadserege. Dezső Tamás nemzetközi hírū magyar tudós kutatásai szerint: az asszír hadseregnek két könnyügyalogos (auxiliáris ijász és lándzsás), két reguláris gyalogos (ijász és lándzsás), három nehézgyalogos (ijász, parittyás és lándzsás) fegyverneme volt (2. ábra).

\section{2. ábra: Asszír harcos. Forrás: Net2.}

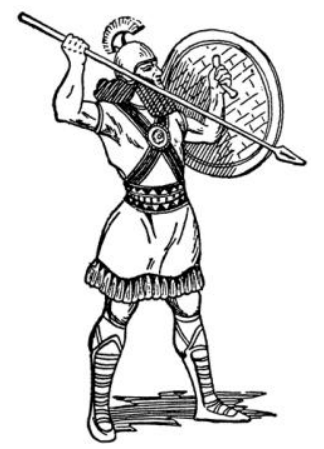

E hét gyalogos fegyvernem mellett kezdetben két lovas fegyvernem (reguláris és testőr/páncélos) volt, de a páncélos ijász és páncélos lándzsás lovasság mellett a szintén páncélos testőrlovassággal, továbbá reguláris valószínúleg páncélozatlan - lovassággal együtt legalább négy lovas fegyvernem léte- 
zett, amelyet sokféle harcikocsizó alakulat legalább háromféle kocsival (könnyű, reguláris és nehéz) egészített ki. Ez a kb. 12 fegyvernem - az írott forrásokból egyáltalán nem rekonstruálható műszaki és ellátó alakulatok nélkül - a hadjáratokon és a csatákban olyan taktikai flexibilitást tett lehetővé, amely az asszír hadsereget a csatatéren szinte legyőzhetetlenné tette (Dezső, 2011).

A korszak „szuperhatalmának” hanyatlása azonban nem a harcmezőn kezdődött el. Adam Schneidernek és Selim Adalinak a Climatic Change szakmai folyóiratban 2014ben megjelent tanulmánya szerint: a régészeti, történeti és paleoklimatikai bizonyítékok mind arra utalnak, hogy a birodalom csillagának leáldozásában a klímaváltozás és a túlnépesedés is - közvetett módon - jelentôs szerepet játszott.

Az erőforrásaiban már korlátozott állam nem volt képes ellenállni a birodalmat sújtó rendkívül súlyos szárazságoknak, mint amilyen az Kr. e. 657-es is volt. Öt év sem kellett hozzá és az asszír állam politikai és gazdasági stabilitása meggyengült, az azt követően kibontakozó polgárháborúk pedig végzetesen megroppantották a több sebből vérző birodalmat (Net3).

Miután a babiloni-méd csapatok elfoglalták Assurt (Kr. e. 614) és Ninivét (Kr. e. 612) Asszíria még megpróbált talpra állni. Kr. e. 605-ben az Eufrátesz folyó melletti Karkemis városa közelében lezajlott ütközetben az ÚjBabilóni Birodalom és a vele szemben álló Asszír, illetve Egyiptom szövetség egyes becslések szerint legalább 30-30 ezer (!) katonát állított hadba. A csatában fontos szerepet játszottak a korszak legfontosabb harci eszközei a harci szekerek. Az Új-Babilóni Bi- rodalom és a méd szövetség győzelme azonban végleg eltiporta Asszíriát és visszaszorította Egyiptomot (Dezső, 2015).

\section{Az Újasszír Birodalom katonáinak juttatásai}

Az asszír katonák juttatásai közzé tartozott a napi élelmiszerellátmány „fejadag” formájában, az alkalmi járandóság sarcból vagy zsákmányból.

„A királyi alakulatoknál a fejadag állománykategóriánként eltérő volt: a közkatonák napi 1 liter (80 dkg) gabonát, a tisztek pedig rangjuknak megfelelően ennél nagyobb - akár kétszereres, háromszoros - ellátmányt is kaphattak. A »király emberei« állomáshelyükön részesültek élelmiszer-ellátmányban. II. Sarrukín az egyik helytartójának parancsba adta, hogy az alatta szolgáló »királyi embereknek« adjon fejenként 1 emāru, azaz kb. 100 liter gabonát. A helytartónak el kellett osztania ezt a gabonamennyiséget a katona és a családja között. A katona 3 sūtu, vagyis 30 liter gabonát kapott »hadjárati fejadagként«, míg családjuknak 7 sūtu, vagyis 70 liter jutott otthoni ellátmányként” - írja Dezső (2015, 205. о.).

Assur-nászir-apli korában (Kr. e. 883 859) jelent meg először a zsákmány, mint Asszíria döntő jövedelmi forrása.

Asszíria a zsákmányon kívül egyszeri megadóztatásként: „hadisarcot” és rendszeres évi adót is követelt a befolyása alatt álló területektől. Az adó megtagadása lázadásnak minősült, amelyet az asszír hadigépezet kíméletlenül megtorolt (Bartha, 1993). 
A zsákmány két fó csoportja az állatok, illetve a fémek voltak. Állatokat (ló, öszvér, szarvasmarha, juh) elsősorban igás- és szállítócélokra (tehát termelőeszközként) zsákmányoltak, a juh azonban mindig „számlálatlanul” került a zsákmányba. A fémeket (arany, ezüst, réz, ólom, vas) főként tömb formájában zsákmányolták és általában fegyver és termelőeszköz készült belőlük. A fennmaradt listák szerint a vas egy évszázad leforgása alatt a zsákmány legnagyobb tételévé emelkedett és a Kr. e. 8. század végén elérte a többszáztonnás nagyságrendet (100-1000 tonna közötti mennyiségek szerepeltek egyegy hadjárat után a feliratokban).

Mivel az asszír hadseregben a vasfegyverek gyártása és tárolása a hadsereg logisztikai rendszerének központi eleme lett, ezért a többszáztonnás vasmennyiség „beszerzése” és az elkészült fegyverek tárolása birodalmi érdek volt. Pl. II. Sarrukín dur-sharukini palotájában 200 tonna vasfegyver tárolására alkalmas fegyvertárat tártak fel. Ilyen nagyságú fegyvertárból több is volt a birodalomban (Richard és Metz, 1991).

Zsákmánycikk volt ezen kívül néhány fényűzési cikk is (elefántcsont-készítmények, alabástrom edények, drágakő, színes kelme, szíriai bor, egzotikus növények, kenet, illóolaj). A zsákmány mennyisége a későbbiekhez képest még jelentéktelen volt, azt azonban már mutatta, hogy Asszíria bevételének legfőbb tényezőjévé vált.
Az asszír zsákmány jellemző vonása volt e korban, hogy meghatározatlan mennyiségú és rendszertelen volt, tehát valóban zsákmány és nem adó és a fiatal, mohó katonai nagyhatalom mindenhol azt és annyit vett el, amennyit csak tudott (Komoróczy, s.a.).

Ezért az Asszíriába visszatérő hadsereg leginkább egy távoli vidékről érkező karavánhoz volt hasonlatos (megjegyzés: asszír újítás volt a szamár helyett az öszvér, illetve a teve, mint „szállítóeszköz” katonai szolgálatba állítása Richard, 2012), rengeteg fogollyal, rogyásig megrakva élelemmel és mindennel, ami mozdítható.

A zsákmány legnagyobb része természetesen az uralkodót illette, mivel ô volt a hadsereg elsőszámú parancsnoka, még akkor is, ha éppen személyesen nem vett részt a hadjáraton. A hadügyekben szakemberek csoportja mai fogalmaink szerinti törzs -, valamint a rangidős tábornok (,turtânu”) - mai fogalmaink szerinti törzsfőnök - állt az uralkodó rendelkezésére. Ez utóbbi pozíció egyre fontosabbá válása vezetett oda, hogy a Kr. e. 7. század utolsó harmadában megkettőzték a hivatalt, ezzel semlegesítve az esetleges személyes ambíciókat.

A birodalom utolsó éveiben az eunuchok vezére („rab ša rêsisi”) volt a legfontosabb tisztség, ugyanis ennek a hivatalnak a viselője állt a hadsereg élén (Vér, 2011).

$\mathrm{Az}$ eunochok vezérének volt egy külön juttatása is. Az utóddal nem rendelkező főeunuchnak a király gondoskodott a temetéséről, túlvilági ellátásáról, sírjának ôrzéséről, az ún: „kispuról”. Vagyis a királyi 
szolgálatban álló eunuchok hűségét nem pusztán a király evilági hatalma szavatolta, túlvilági jólétük egyetlen garanciáját is csak az uralkodóban láthatták (Vér, 2011).

A fennmaradt zsákmánylisták alapján a tábornokok, (fö)tisztek, tiszthelyettesek és a közkatonák eltérő mértékben részesültek a zsákmányból. A tiszti, tiszthelyettesi kar hierarchiája a vezetett egységek létszáma szolgált alapjául (tíz, ötven, vagy száz ember vezetője), de általánosak voltak az olyan címek is, mint a főtiszt „kapitány” (,rab kișir”), vagy a „táborszernagy” (,rab urâte”), akik a birodalom legnagyobb katonai dinasztiáiból kerültek ki (Joannés, 2004). Természetesen ők jóval nagyobb részt kaphattak a zsákmányból, esetenként földbirtokban és a foglyok közül kiválasztott rabszolgákban is részesültek.

Ennél jóval szerényebb juttatásra voltak jogosultak az alacsonyabb beosztásúak. „Egy fennmaradt zsákmánylista szerint az udvari szolgálatot ellátó lovassági tisztek (tiszthelyettesek) között kiosztott zsákmánynál a fogatparancsnok tiszt (,lú.gal-ú-rat”) 7 mina (kb. 3,5 kg) rezet, 2 juhot és 2 korsó bort, míg a kocsihajtó tiszthelyettes („lú.mu-kil-pa.meš”) mindössze 1 juhot és 1 korsó bort kapott" (Dezső, 2015, 205.).

Mielőtt rátérnénk a katonák legjelentősebb juttatására a földbirtok adományra, a szolgálati földre, tekintsük át a korszak földtulajdon viszonyait! Az Újasszír Birodalom mag-, és meghódított területei királyi tulajdonban voltak. Egy részüket a király magas rangú katonái és az államapparátus felsô rétegének kezébe adta. A földek jogilag nagybirtokok voltak, mûvelésük azonban kis, néhány - legfel- jebb 5 - hektár kiterjedésű telepekre osztva folyt. A telkeket azok a telepesek kapták meg, akiket családjukkal együtt hurcoltak el és telepítettek le. Jogilag a telepesek a földet használó nagybirtokos vagy a király tulajdonában voltak, el is lehetett óket adni, de csak a telekkel együtt. A telek használata fejében múvelői uruknak földjáradékot fizettek: a föld nagysága, fekvése (csatornától való távolsága) és értéke alapján meghatározott összegú díjat, részben természetben és szolgáltatásokban, részben pedig pénzben. A földjáradék akár a termés egyharmadát is elérhette. A katonai arisztokrácia tagjai így jelentős jövedelemre és ezáltal igen nagy hatalomra tettek szert, az uralkodóval vetekedve szinte „kiskirályként” uralkodtak.

A III. Tukulti-apil-Esarra (3. ábra) ezt korlátozta és magas rangú tisztjeinek adománybirtokát sohasem egy tagban adta ki, hanem 20-25 hektár területű darabonként, egymástól távol fekvő körzetekben. Ezzel lehetetlenné

\section{3. ábra: III. Tukulti-apil-Esarra reliefje. Forrás:} Net4.

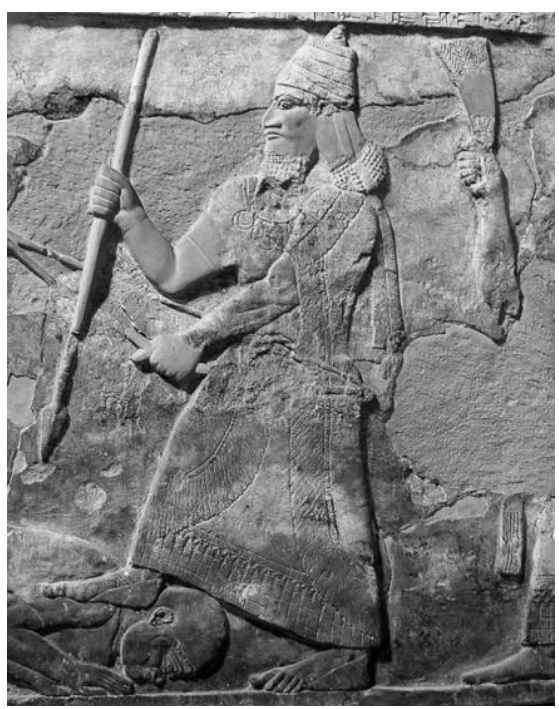


tette a katonai arisztokrácia esetleges területi alapon szervezett ellenállását (Komoróczy, s.a.). Azonban az asszír tiszteknek juttatott szolgálati birtokok, eltérően a közkatonáéktól szabadpiaci forgalomba kerülhettek. Dezső Tamás (2015) kutatásai szerint egyetlen olyan fennmaradt szöveg lelhető fel, amely a könynyű gyalogsághoz tartozó közkatonák - az auxiliáris îjászok - szolgálati birtokáról szól. Egy királyi parancs mentesítette az ijászok „,ijföldjét" a gabona és szalmaadó alól. Ezért lehet ez az ,ij-fóld” jó eséllyel egy, az ijász alakulatok közkatonáinak juttatott - nem forgalomképes - szolgálati birtoktípus.

A magas társadalmi pozíciójú katonatisztek is részesülhettek adómentességben, azonban birtokaik közül csak azok voltak adómentesek, amelyekre a királyi adománylevél vonatkozott. Azok, amelyeket a tisztek vásároltak, az adózás hatálya alá estek.

\section{Az özvegyek és árvák helyzete az újasszír katonai birodalomban}

Az asszír törvények közül egy sem kötelezte az uralkodót vagy valamely közhivatalt arra, hogy gondoskodjék az özvegyekről, árvákról vagy a szegényekről.

A Kr. e. 18. és 12. század között fennálló Hettita Birodalom - amely az Újasszír Katonai Birodalom és Egyiptom mellett a Földközi-tenger térségének korabeli harmadik nagyhatalma volt - az özvegyekről is gondoskodott.

A fennmaradt cserépkönyvtárak írásemlékei szerint: „,ha a férfi meghalt, feleségül vette a meghalt férj fivére akekor is, ha már nös volt, fivér biányában pedig az apa”. A levir házas-

\begin{abstract}
ság alaprendeltetése modern fogalmaink szerint „özvegy-, gyermek- és családvédelmi” jellegű. Funkciója az özvegyek és velük a gyermekek, vagyis a nemzetségi folyamatosságot fenntartó generáció nemzetségen belül tartásának - nemzetségi hovatartozásának, státuszának és javainak - biztosítása volt, a megözvegyült anya házassággal szerzett nemzetségi jogai és jogállapota folyamatosságának biztosítása által (Szádeczky-Kardoss, 2012, 185. o.).
\end{abstract}

A trónjukért és az ország biztonságáért való tengernyi gond közepette az asszír zsarnokoknak nem maradt idejük az efféle apró ügyekre. Az uralkodók ezt egyszerūen elintézték, mivel propagandisztikus célból kinyilvánították: „... hogy a hatalmas a gyengét meg ne károsithassa”. Bár a parancsot agyagban vagy fémen rögzítették, annak kötelező ereje nem volt, mivel az azt megszegőket az istenek büntetésével és átkaival fenyegették, és érvényesítését az alattvalók mély vallásos meggyőződére bízták (Klíma, 1983).

A társadalom elesettjeivel szembeni teljes részvétlenséget árnyalja - a Kr. e 721-705 között uralkodott - II. Sarrukín asszír király (4. ábra) egyik fennmaradt levele. Ebben arra utasítja az egyik helytartóját, hogy vizsgálja meg a tartományában, hogy az elesett katonák özvegyeit, árván maradt fiait és lányait nem vetette-e valaki szolgaságba.

Az ilyen típusú gondoskodásnak akkor volt különös jelentősége, ha az özvegy és az árvák örököltek az elesett után, mivel a levél megemlíti, hogy azokat a fiúkat nem kell lejelenteni a királynak, akik apjuk helyett beálltak a seregbe. 
4. ábra: II. Sarrukin asszír király. Forrás: Net5.



Tehát az újasszír kor uralkodói az elesett katonáik özvegyei és árvái irányában sem voltak teljesen érzéketlenek. Azonban ebben az az önös érdek is vezérelte őket, hogy a fiúk örökletes szolgálatával hadseregük ütôképességét továbbra is fenntartsák (Tamás, 2016).

\section{Irodalom}

Bartha Tibor (1993) (Szerk). Keresztyén bibliai lexikon. Magyarországi Református Egyház Kálvin János Kiadója, Budapest.

Dávid Antal (1928): Bábel és Assur II. Történet, Szent- István-Társulat az Apostoli Szentszék Könyvkiadója, Budapest. Letöltés ideje: 2020.04.02. Web: http://www.ppek.hu/facsimile/David_A ntal_Babel_es_Assur_II_facsimile.pdf

Dezső Tamás (2011): Hosszú út a győzelemig - Az asszír hadsereg alakulatainak útja a helyőrségektől a csatatérig. In Bács Tamás, Dezső Tamás, Niederreiter Zoltán (szerk.). 100 év után - Emlékekonferencia a Keleti Népek Ókori Története Tanszék alapitásának 100. évfordulóján. ELTE Eötvös Kiadó, Budapest. 123-139.

Dezső Tamás (2015): Az asszír hadsereg gazdasági és társadalmi háttere. In Bács Tamás, Dezső Tamás, Vér Ádám (Szerk.): Aegyptiaca et Assyriaca - Tanulmányok az Eötvös Loránd Tudományegyetem Ókortudományi Intézetéből. ELTE Eötvös Kiadó, Budapest. 201-213.

Dömötörfi Tibor (2010): Erőszak az ókorban - Barbárok, zsarnokok, háborúzó ellenfelek. História magazin, 2010/5. 5-34.

Hahn István (1963). A hadmüvészet ókori klaszsqikusai. Zrínyi Katonai Kiadó, Budapest.

Joannés, Francis (2004): Az asszír hadsereg szervezete. In Francis Joannés (Ed.): The Age of Empires - Mesopotamia in the First Millenium. BC. Edinburgh University Press, Edinburgh. 54-60. Letöltés ideje: 2020.03.20. Web: https://dlukacs. wordpress.com/2009/07/04/francisjoannes-az-asszir-hadsereg-szervezete/

Kajtár István, Herger Csabáné (2014): Egyetemes állam-és jogtörténet. Dialóg Campus Kiadó - Nordex Kft.

Kalla, Gábor (2003) Az asszír főváros és a királyi propaganda - Ninive példája. Ókor: folyóirat az antik kultúráról, 2 (1). 9-18. Letöltés ideje: 2020.03.30. Web: http:/ /www.ookor.hu/archive/cikk/2003_1_ka lla.pdf

Klíma, Josef (1983). Mezopotámia. Ösi civilizáció és kultura a Tigris és az. Eufratész. mentén. Gondolat Kiadó, Budapest.

Komoróczy Géza (s.a.): Mezopotámia története az öskortól a perzsa bódításig (Kr. e. 539) Elektronikus kiadás: Terebess Ázsia E- 
Tár. Letöltés: 2020.02.02. Web: https:// terebess.hu/keletkultinfo/mezopotamia.h tml

Lóránt Károly (2018): Mezopotámia, a piacgazdaság hajnala. Hitel folyóirat, 31. (7.). Letöltés: 2020.03.03. Web: http://www. hitelfolyoirat.hu/sites/default/files/pdf/1 0-lorant.pdf 1

Pais István (1993): Bibliai érdekességek, történetek, aforizmák. Magánkiadás, Budapest.

Richard A. Gabriel (2002): The Great Armies of Antiquity. Praeger Publishers, United Stated of America.

Richard A. Gabriel, Metz, Karen S. (1991): From Sumer to Rome: The Military Capabilities of Ancient Armies. Greenwood Press, New York.

Saggs, H. W. F (1965). Everyday life in Babylonia and Assyria. Assyrian International News Agency Books Online 61. Letöltés ideje: 2020.03.20. Web: http:// www.aina.org/books/eliba/eliba.pdf

Szádeczky-Kardoss Irma (2012): Tûzzelvassal avagy türelemmel. Egy romlott szövegű Szent István-i kapitulum rekonstruálása és értelmezési konzekvenciái. $M a$ gyar Sion Új folyam. VI.(XLVIII.) évfolyam. 2. szám. 183-201.
Tamás Dezső (2016). The Assyrian Army II. Recruitment and Logistics. Eötvös University Press, Budapest.

Vér Ádám (2011): Az Újasszír Birodalom keleti expanziója. Doktori disszertáció. Letöltés: 2020.03.01. Web: http://doktori.btk.elte. hu/hist/veradam/diss.pdf

\section{Internetes források}

Net1: Asszír harciszekér. Letöltés ideje: 2020.04.19. Web: https://www.science source.com/archive/Assyrian-Warriors-Two-Wheeled-Chariot-SS2718396.html

Net2: Asszír harcos. Letöltés ideje: 2020.04.19. Web: https://stmuhistory media.org/assyrians-more-than-warriors/

Net3: Too many people, not enough water: Now and 2,700 years ago. University of California, San Diego. Letöltés ideje: 2020.03.02. Web: https://www.eure kalert.org/pub_releases/2014-11/uoc-tmp111014.php

Net4. III. Tukulti-apil-Esarra reliefje. Letöltés ideje: 2020.04.19. Web: https:// allmesopotamia.wordpress.com/tag/tukul ti-apil-esarra/

Net5: II. Sarrukín asszír király. Letöltés ideje: 2020.04.19. Web: https://alchetron. com/Sargon-II\#sargon-ii 